\title{
Evaluating the applicability of rheometry in steel fiber reinforced self-compacting concretes
}

\section{Avaliação da aplicabilidade de reometria para concretos autoadensáveis com fibra de aço}

R. S. ALFERES FILHO a

alferes.ricardo@gmail.com

F. K. MOTEZUKI a

fmote@usp.br

R. C. O. ROMANO a

rcorjau@gmail.com

R. G. PILEGGI a

rafael.pileggi@gmail.com

A. D. FIGUEIREDO a antonio.figueiredo@usp.br

\begin{abstract}
The use of self-compacting concrete in civil construction industry presents various advantages, since the material shows adequate workability during fresh state. When fiber reinforcement is used, there are changes in its behavior that require attention. This study aimed to evaluate the applicability of rheological tests and the correlation between its results and those obtained with regular tests used to control SCCs. In that sense, different mixtures of SCC with different steel fiber contents were produced in order to be analyzed in the experimental program described. Rotational rheology tests and slump flow and L-box tests were performed. The results showed that slump flow test did not present good correlations with rheological parameters. On the other hand, this test was able to point out the risk of segregation of the mixtures with higher fiber contents. A good correlation was obtained between the L-box test results and rheological parameters. The L-box was also able to show loss in the passing ability of SCC related to the rise of plastic viscosity and yield stress. These tests also presented a good correlation with the rheological parameters when lower fiber contents were used. Although the rheometry test was unable to evaluate these problems, this kind of test gave more objective and reliable data on variations in rheological parameters related to the increase of fiber content, and proved to be a more reliable test to this kind of application, especially when applied together with the conventional tests.
\end{abstract}

Keywords: self-compacting concrete, steel fibers, I box, slump flow, rheology.

\section{Resumo}

O uso de concreto autoadensável na construção civil apresenta várias vantagens, desde que o material apresente trabalhabilidade adequada no estado fresco. Quando é utilizado o reforço com fibras, há alterações nas propriedades no estado fresco, que nem sempre são detectadas com a utilização de ensaios convencionais normalizados. Este estudo buscou avaliar o potencial de aplicação de ensaios reológicos e a relação com os ensaios comumente utilizados para aceitação de CAAs. Com essa finalidade, foram elaboradas misturas de CAA com fibras de aço em diferentes teores e realizaram-se ensaios de reometria rotacional, espalhamento e Caixa L. Os resultados mostraram que o ensaio de espalhamento não apresentou boa correlação com os parâmetros reológicos medidos, mas permitiu detectar o risco de segregação dos concretos com maior teor de fibras. O ensaio de caixa $L$ obteve boa correlação com os valores obtidos no reômetro, demonstrando perda na habilidade passante em função do aumento da viscosidade plástica e tensão de escoamento, especialmente para baixos teores de fibras, mas apresentou bloqueio entre barras para grandes quantidades de fibras. O ensaio de reometria forneceu dados mais objetivos sobre variação nos parâmetros reológicos, apontando um comportamento pseudoplástico do concreto utilizado no trabalho. Ficou claro o aumento da viscosidade com o aumento do teor de fibras como uso da reometria, fornecendo informações confiáveis mesmo para maiores teores de fibras. Isto comprova que a reometria é um ensaio bastante adequado para este tipo de aplicação.

Palavras-chave: concreto autoadensável, fibras de aço, caixa I, espalhamento, reologia.

Universidade de São Paulo, Departamento de Engenharia Civil, Escola Politécnica, São Paulo, SP, Brasil. 


\section{Introduction}

The use of self-compacting concrete (SCC) brings important changes to the concrete casting process, by changing its behavior in fresh state. Since SCC does not require the use of vibration, the casting process became easier even when there is dense reinforcement or more complexes geometries [1].

Aydin [2] indicates that SCC increases the efficiency of fiber reinforcement usage because it makes possible the usage of a higher fiber volume in fresh concrete maintaining its workability through fluidity improvement. This is a great advantage when a higher post-cracking strength is required for fiber reinforced concrete (FRC), which could assure a reduction in steel bars or even their total replacement in some uses [3]. However, there are doubts about the ability of SCC to keep its workability conditions constant when fiber content increases because the fiber could change the consistency of cementitious materials $[4,5]$. The influence of fiber in the cement paste has been studied by Martinie et al [5] who concluded that the increase in fiber volume leads to an increase in yield stress in pastes. The authors affirm that the results can be extrapolated to situations involving concrete and mortars. However, it is worth noting that fibers with distinct geometries affect the concrete in different ways. Previous study [6] demonstrates that, the higher the fiber aspect ratio is, the higher is its impact in the workability of regular concrete.

Tests like L Box, Slump Flow and V Funnel are commonly used to assess this kind of suspension due to their easier use, although they only provide a single point result information about the fresh state characteristics of the concrete. Furthermore, the results obtained are not expressed in terms of physical parameters [7, 8], and there are previous studies that had pointed out that these tests are not appropriated to fiber reinforced concrete [4]. On the other hand, there are other studies that have used these tests as a base for the analysis of fiber reinforced self-compacting concrete (FRSCC) [4, 9-13]. The use of rotational rheometry permits to evaluate the characteristics of FRSCC in different shear stress conditions. That condition brings to the rheometer a higher capacity of evaluation, enabling its usage as physical criteria to comprehend the results obtained by the single point tests [14]. Thus, this experimental work was carried out aiming to evaluate the applicability of planetary rotational rheometry to evaluate the workability of steel fiber reinforced self-

\section{Figure 1 - Flowchart of the steps of the experimental study}

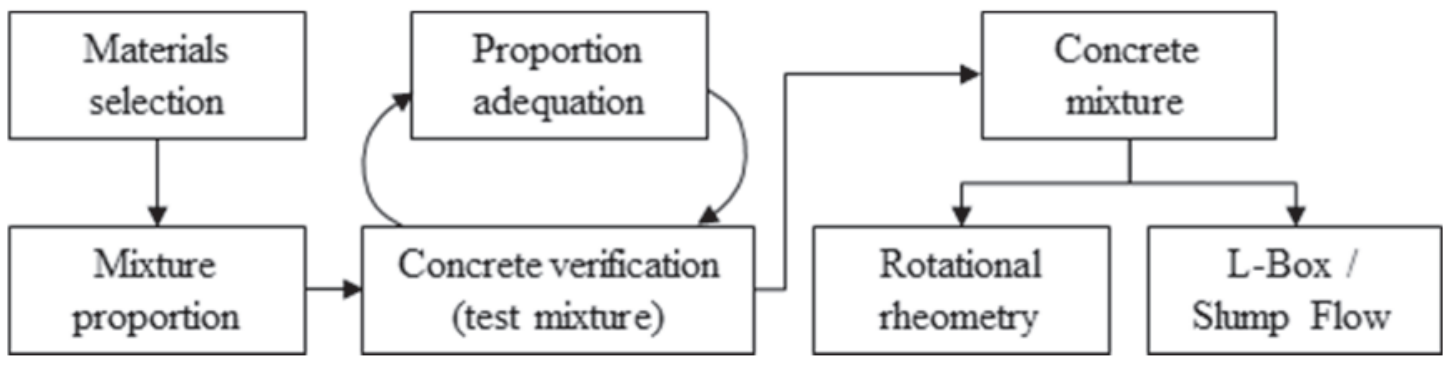

Figure 2 - Particle size distribution of the materials and fiber used in the study
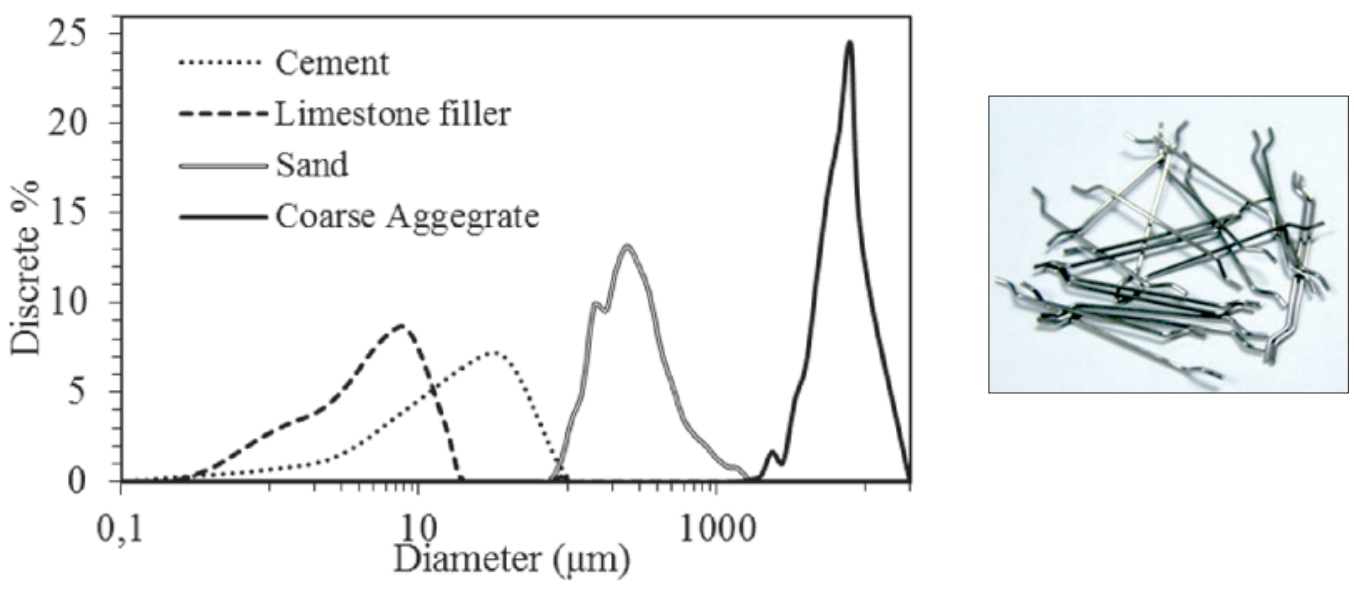


\section{Table 1 - Material proportion of the designed concrete}

\begin{tabular}{ccccc} 
Material & $\begin{array}{c}\text { Mixture proportion } \\
\text { by cement weigth }\end{array}$ & $\begin{array}{c}\text { Consumption } \\
\left(\mathrm{kg} / \mathrm{m}^{3}\right)\end{array}$ & $\begin{array}{c}\text { SSA } \\
\left(\mathrm{m}^{2} / \mathrm{g}\right)\end{array}$ & $\begin{array}{c}\text { Density } \\
\left(\mathrm{g} / \mathrm{cm}^{3}\right)\end{array}$ \\
$\begin{array}{c}\text { Cement } \\
\text { Limestone filler }\end{array}$ & 1,0 & 522 & 1,2 & 2,96 \\
Sand & 0,12 & 63 & 3,6 & 2,69 \\
Coarse aggregate & 2,0 & 1044 & 0,6 & 2,40 \\
\hline
\end{tabular}

compacting concrete and correlate its results with those obtained by the conventional tests applied to SCC.

\section{Experimental programme}

In order to achieve the objectives of this study, one type of steel fiber was selected and its consumption was varied. This allowed the study to make clear the influence of fiber content in the rheological behavior of the concrete. The maximum fiber content used was $120 \mathrm{~kg} / \mathrm{m}^{3}$. This research was then developed according to the scheme presented in Figure 1

The different mixtures produced for this study were made in a conventional mixer as detailed below. After mixing, the mixtures were submitted to conventional and rheological tests simultaneously. The simultaneous execution of the tests was adopted to ensure that the fresh concrete properties would not be influenced by the loss of the effect of superplasticizer or cement early hydration. These tests are detailed in item 3.

\subsection{Materials}

The self-compacting concretes were made with crushed granite stone, sand, Portland Cement (Brazilian type CP II F 32, Votoran) and limestone filler (Profine 1, Provale) with particle size distribution determined by dynamic image analysis in a Qicpic equipment (Sympatec) as shown in Figure 2.

Hooked ends steel fibers with $30 \mathrm{~mm}$ of length and aspect ratio of 47.6 (Figure 2) were used. Short fibers were used according to the traditional empirical recommendation for minimum fiber length, which must be greater or equal to twice the maximum diameter of the coarse aggregate (Lfiber $\geq 2$ pmax of coarse aggregate), which was $9.5 \mathrm{~mm}$ in this study. This recommendation aimed to make more efficient the post-crack strengthening of FRC [15].

A sodium polycarboylate based high performance superplasticizer (Grace ADVA 585) was used in all mixtures in a constant content by cement weight. This admixture is usually applied to fine particles stabilization and as a mixing water reducer.

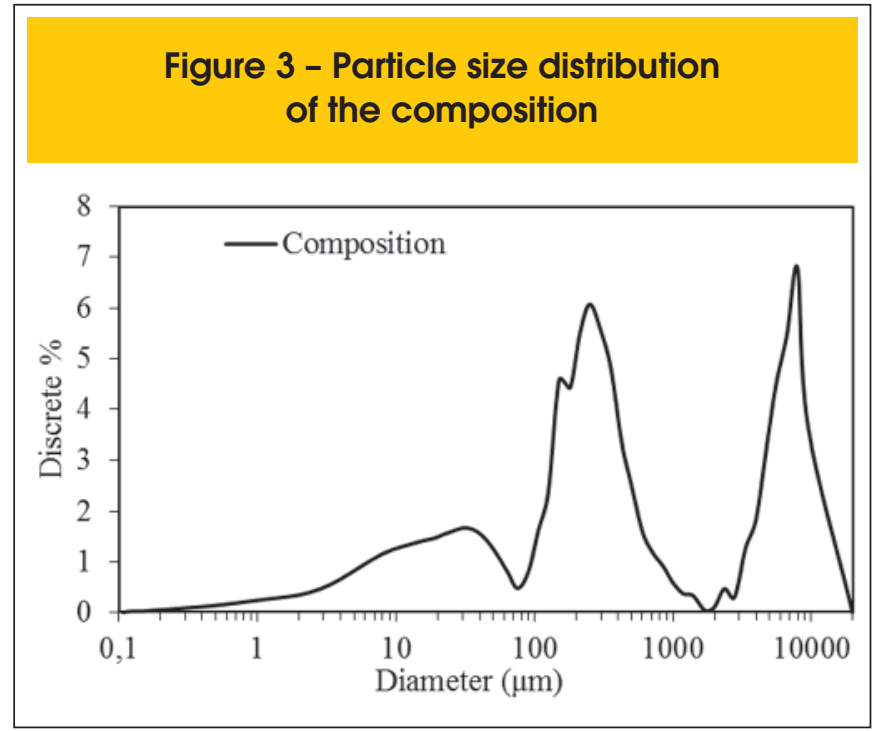

\subsection{Concrete composition}

The base of the composition of the concrete used in this study is shown in Table 1, and it was developed considering formulations available in the literature for the same type of concrete and with similar fiber content $[13,16]$. Therefore, no conventional mix design method was used in this study.

Table 1 presents the specific surface area (SSA) and the density of each raw material used is presented. The SSA was quantified in a Belsorp Max equipment (Bel Japan) and the density of each material was determined in a He gas pycnometer (Quantachrome MVP 5DC).

The resultant particle size distribution is show in Figure 3 and the water/cement ratio was 0.4 , kept constant in all mixtures.

Table 2 provides the fiber content values in terms of kilograms per cubic meter of concrete and by volume fraction used in the experiment. The values were chosen aiming to reach a range that

\section{Table 2 - Fiber consumption in concrete mixtures}

\begin{tabular}{|ccccccc}
\hline & Mixture & & 1 & 3 & 4 \\
Fiber content & $\left(\mathrm{kg} / \mathrm{m}^{3}\right)$ & 0 & 20 & 80 & 120 \\
& $(\% \mathrm{vol})$ & $0,00 \%$ & $0,25 \%$ & $1,02 \%$ & $1,53 \%$ \\
\hline
\end{tabular}




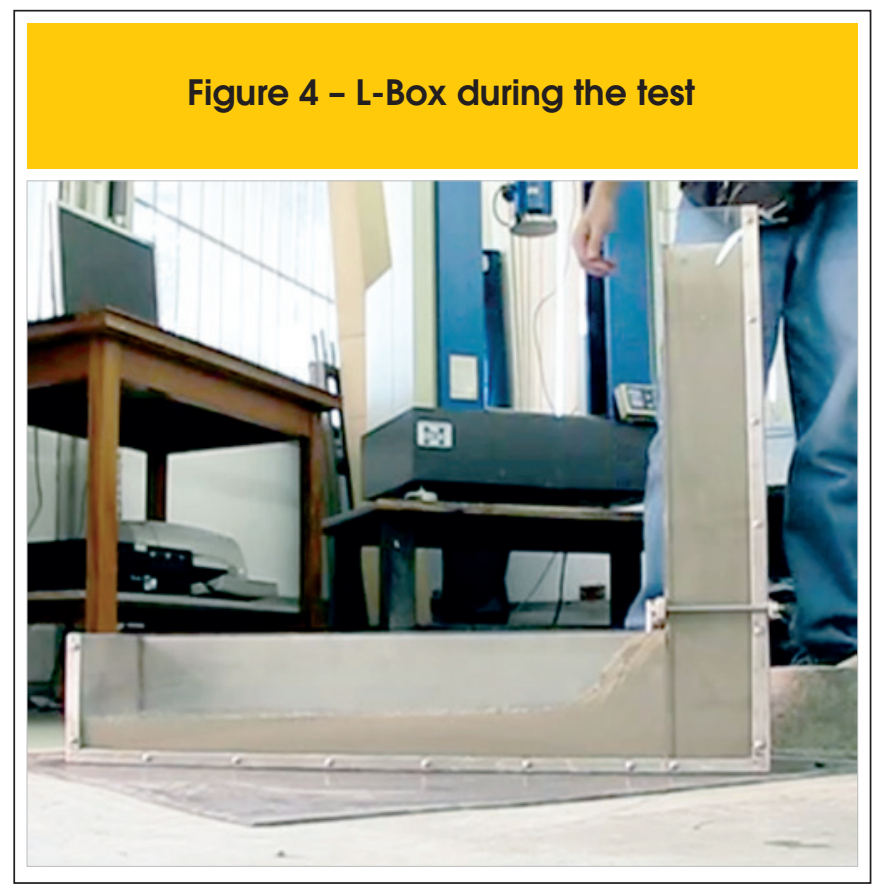

makes clearer the influence of fiber in the rheological behavior of FRSCC.

\subsection{Concrete mixing process}

The concrete mixing process was made in conventional concrete mixer with inclined axis, and a total capacity of $120 \mathrm{I}$. The mixing procedure adopted was the same for all mixtures to avoid any influence of intervening variables originated in this stage. The mixing procedure followed the sequence below:

1. Moistening the mixer;

2. Coarse aggregate introduction;

3. Introduction of $50 \%$ of the water and the mixer was turned on for 1 minute;

4. Introduction of the fine aggregate and mixing for 1 minute;

5. Introduction of cement and filler, and mixing for 1 minute;

6. The remaining water and admixture was added;

7. The fibers were added gradually during the next 5 minutes of continuous mixing in order to avoid the formation of clumps. After the mixing was complete, samples were taken to be tested in L-box, Slump Flow and rotational rheometry tests, which were done at the same time, as described in item 2.

\section{Test methods}

\section{$3.1 L-B o x$}

The L-Box test aims to assess the passing ability of self-compacting concrete, which is the capacity of flowing through narrow spaces between steel bars and maintaining homogeneity and the capacity of filling up the formwork without showing phase separation or material blocking [17]. The three steel rebars with a diameter of $12 \mathrm{~mm}$ were kept in the tests with the intention of evaluating a particular condition of workability for hybrid reinforcement, that is the passing ability of FRSCC. This alternative reinforcement has been used in various applications [18-20] with the aim of optimizing the mechanical behavior of structural elements.

In the conduction of the L-Box test, the prismatic column was filled with FRSCC and, after 60 seconds, the floodgate was opened to start the concrete flow. The clear side of the L-Box allows observing the concrete flowing as illustrated in Figure 4.

The result of this test is given by a relationship between the heights

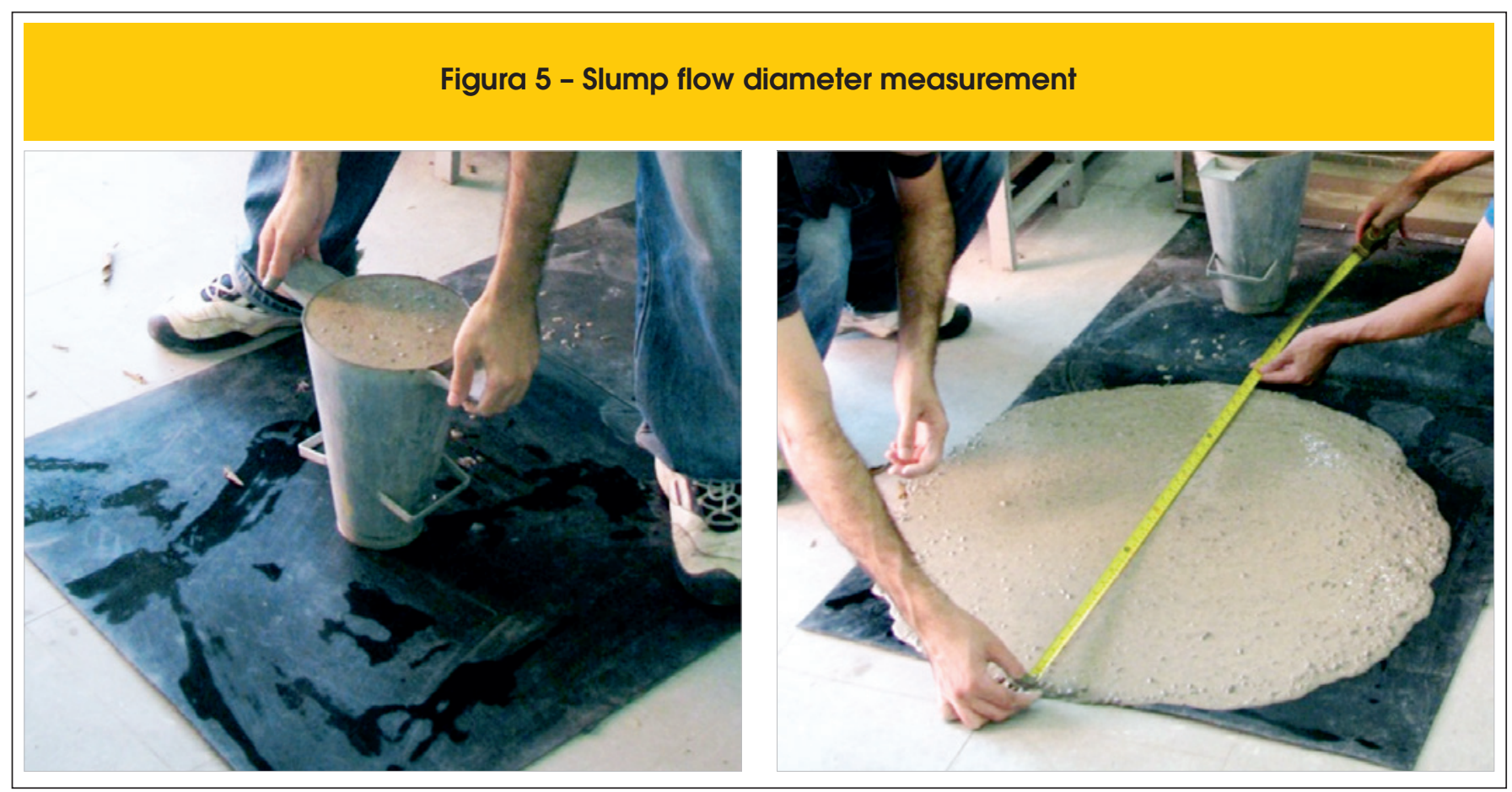


of the concrete layer on both edges of the horizontal prism. The passing ability of the concrete is more efficient if the ratio value is closer to one. Values considered acceptable for self-compacting concrete should be in the range from 0.8 to 1 [17].

\subsection{Slump flow}

The Slump Flow test has similarities with the Abrams slump test. This test is used to assess the concrete flowing capacity in unconfined situations under the action of their own weight [21].

For this study, the cone was filled in the inverted position with the intention of making the initial flow oriented and more restrictive. Although this differs from the position suggested by certain technical standards, there is an indication that there is little influence related to the direction of the cone [22]. So, this set up was chosen in order to provide the most critical assessment condition for FRSCC. Two diameters measures are made in two mutually perpendicular axis after the remotion of the cone and spreading of the concrete, as shown in Figure [5]. There is no consensus in the technical literature about the spreading limits. For this work, the values used as reference were taken from EFNARC [17], ranging 650-800 mm, similar to those adopted by Akcay and Tasdemir [23].

Although the Slump Test result is expressed only by the measured diameters, this method allows to visual assessment of segregation occurrence or water bleeding. However, this is a qualitative indicator and therefore not measurable as acceptance criteria [17], but it can help in assessing the suitability of the mixtures used.

\subsection{Rotational rheometry}

A planetarium rheometer built at Polytechnic School of University of São Paulo was used in the tests as shown in Figure 6a. The test consists in inducing shearing in a volume of approximately 18 liters of concrete inside a metal recipient with shearing elements adapted for testing the concrete. These shearing elements were especially designed aiming to decrease segregation.

The material was homogenized during the first 80 seconds of the test in order to prevent materials segregation. That procedure was adopted since the mixing was done in the mixer and the concrete had to be subsequently moved into the equipment. Then a shear cycle was applied, varying the rotation speed from 50 to $1000 \mathrm{rpm}$ and returning at $50 \mathrm{rpm}$. The speed was maintained for 7 seconds at each level, as illustrated in Figure 6b.

The results were compiled in a graph (for details see Fig 9) showing rotation versus the applied torque. The yield torque and plastic viscosity were obtained from the Bingham rheological model applied in the rotation deceleration stage. This procedure was used aiming to guarantee the better dispersion of the particles after the imposition of the highest shear condition in the first stage of the test. The parameters were then determined correlating the results with a linear trend line. So, slope was taken as a parameter for viscosity evaluation and the intersection with the ordinate axis as a parameter for yield stress evaluation.

\section{Results and discussion}

\subsection{Single point tests (L Box and Slump Flow)}

The results obtained from the L-box and Slump Flow tests, related to the fiber content, are presented in Table 3. As reference criteria for these results, the values proposed by EFNARC [17] were adopted. In the L-Box test, the higher the fiber content, the lower is the proportion between the vertical sections. So, the difference between the height at the beginning and in end of the horizontal prism is increased with the fiber content. This shows that the fibers obstruct the mobility of the SCC. Only the concrete without fiber and the

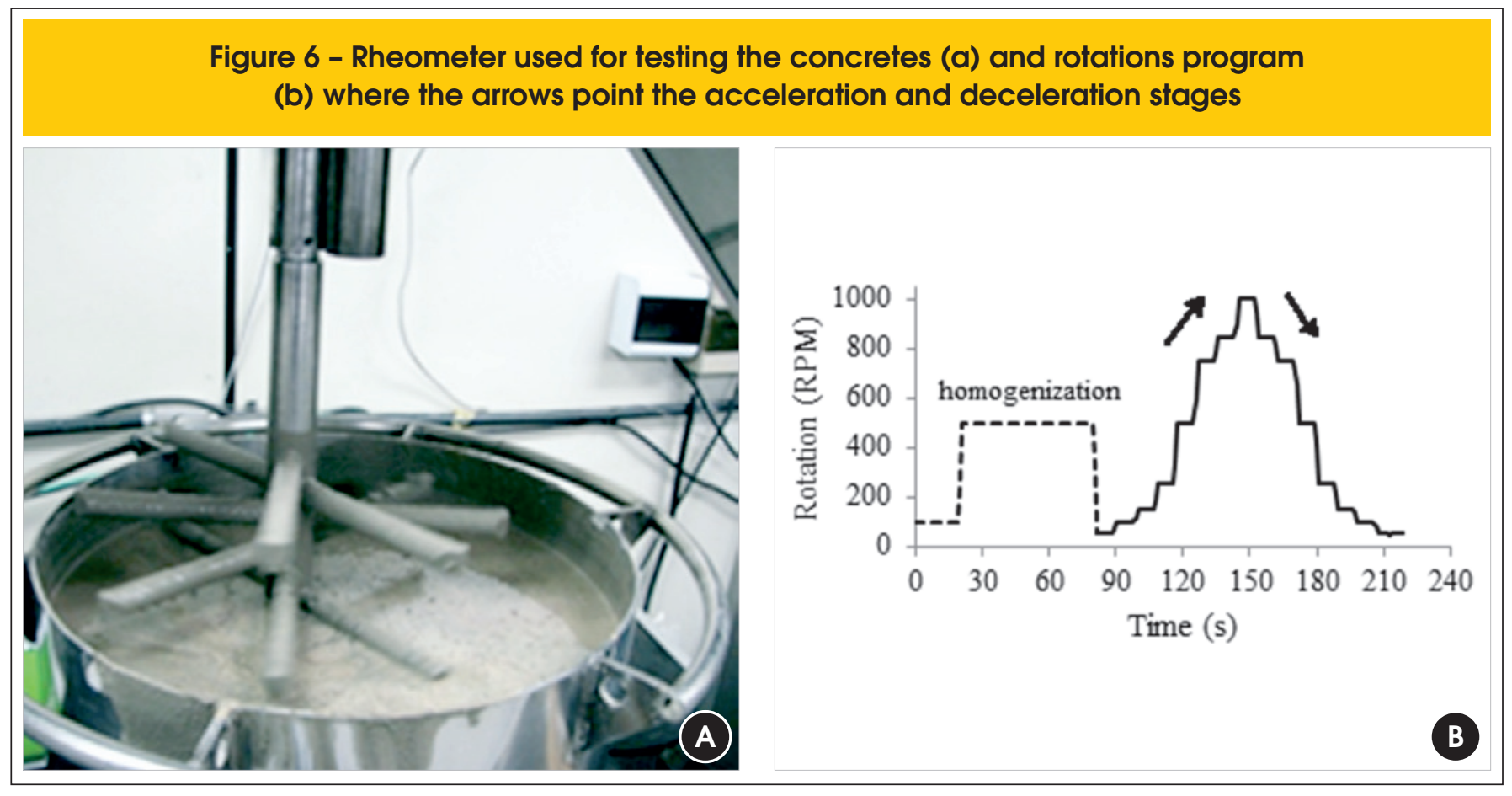


Table 3 - Results of the standard tests

\begin{tabular}{|ccccccc|}
\hline $\begin{array}{c}\text { Flber content } \\
\left(\mathrm{kg} / \mathrm{m}^{3}\right)\end{array}$ & 0 (Ref) & 20 & 80 & 120 & \multicolumn{3}{c|}{ Limits (EFNARC) } \\
\hline L-Box (h2/h1) & 1,0 & 1,0 & 0,74 & 0 & 0,8 & 1,0 \\
\hline Slump flow $(\mathrm{mm})$ & 785 & 795 & 775 & 780 & 650 & 800 \\
\hline
\end{tabular}

one with the lower content showed results within the limits recommended by EFNARC [17]. Therefore, only these concretes could be considered self-compacting by this criterion.

The fiber consumption of $80 \mathrm{~kg} / \mathrm{m}^{3}$ resulted in a ratio of 0.74 in the L-Box test, lower than the minimum recommended for application as self-compacting [17]. A partial blocking of the material at the metal rebars could be observed for FRSCC with this fiber consumption (Figure 7a), which leaded to an heterogeneity of fiber distribution in the fresh concrete.

For the fiber consumption of $120 \mathrm{~kg} / \mathrm{m}^{3}$ (Figure $7 \mathrm{~b}$ ), the impact of the rebars was even higher and there was no significant flow during the test. Almost all the material was blocked behind the rebars, with a small amount of paste flowing through the horizontal section with negligible volume. Therefore, the result was quantified as zero ratio. These results are important because they show that the test setup used in mixtures without fiber or low fiber content is not suitable for higher fiber volumes, making it infeasible after a certain value. Similar results were obtained in the study of Dhonde, Mo and Hsu [24]. However, if the FRSCC is not intended for molding an element with hybrid reinforcement, it would be interesting to remove the steel bars to better assess the material.

From the Slump Flow tests, differently from observed in L-Box results, all concrete mixtures would be considered within the recommended range for SCCs [17]. The results are similar with the ob- tained in the research of Akcay and Tasdemir [23], which obtained Slump Flow diameters that did not show significant variation even in concretes with higher fiber content. However, there was notable segregation in the concrete with higher fiber content compared to the reference concrete, as seen in Figure [8]. There were clustering happening at the central portion of the sample during the Slump Flow. This fact occurs due to the interlocking of the fibers, which also acts as a barrier to the flow of coarse aggregates. Thus, it was observed considerable phase separation. The fine materials, and part of the coarser, flowed through the border, similarly to the behavior that was observed by Grünewald and Walraven [25]. Although described in technical standards, the criteria that defines segregation during Slump Flow test is very subjective and relies on the judgment of those responsible for the interpretation of results. This phenomenon was very clear in the case of concrete with fiber content of $120 \mathrm{~kg} / \mathrm{m}^{3}$, but this observation was not very pronounced in the other concretes. Thus, according to technical standard indications, the concrete with the higher fiber content should not be considered self-compacting.

From these results, it is possible to point some limitations in Slump Flow test when higher amount of fibers are used. The first one is the fact that the measurement can be affected by factors such as fibers interlocking, which is a phenomenon that is difficult to quantify although it can be easily observed. Furthermore, the measured

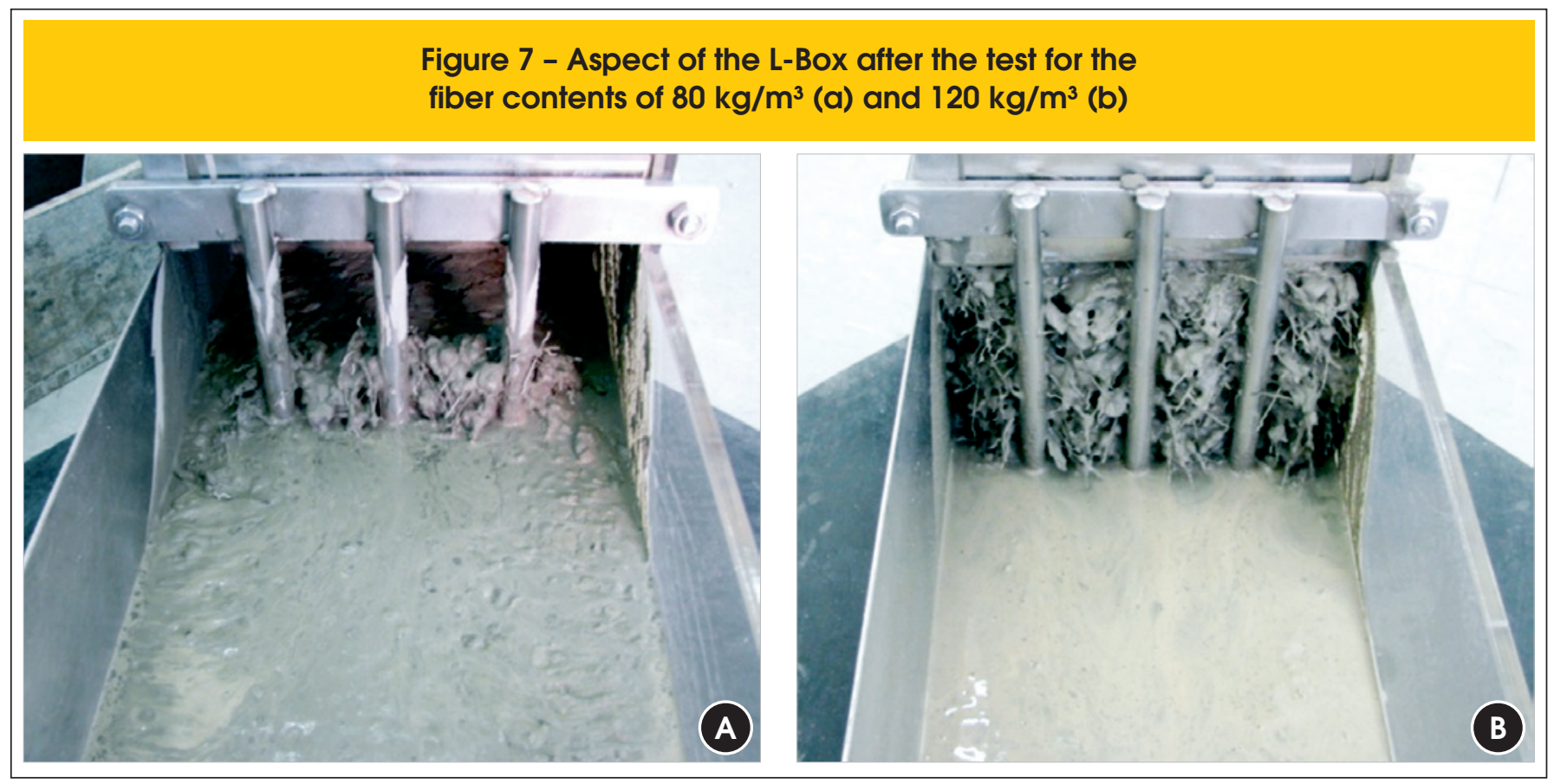




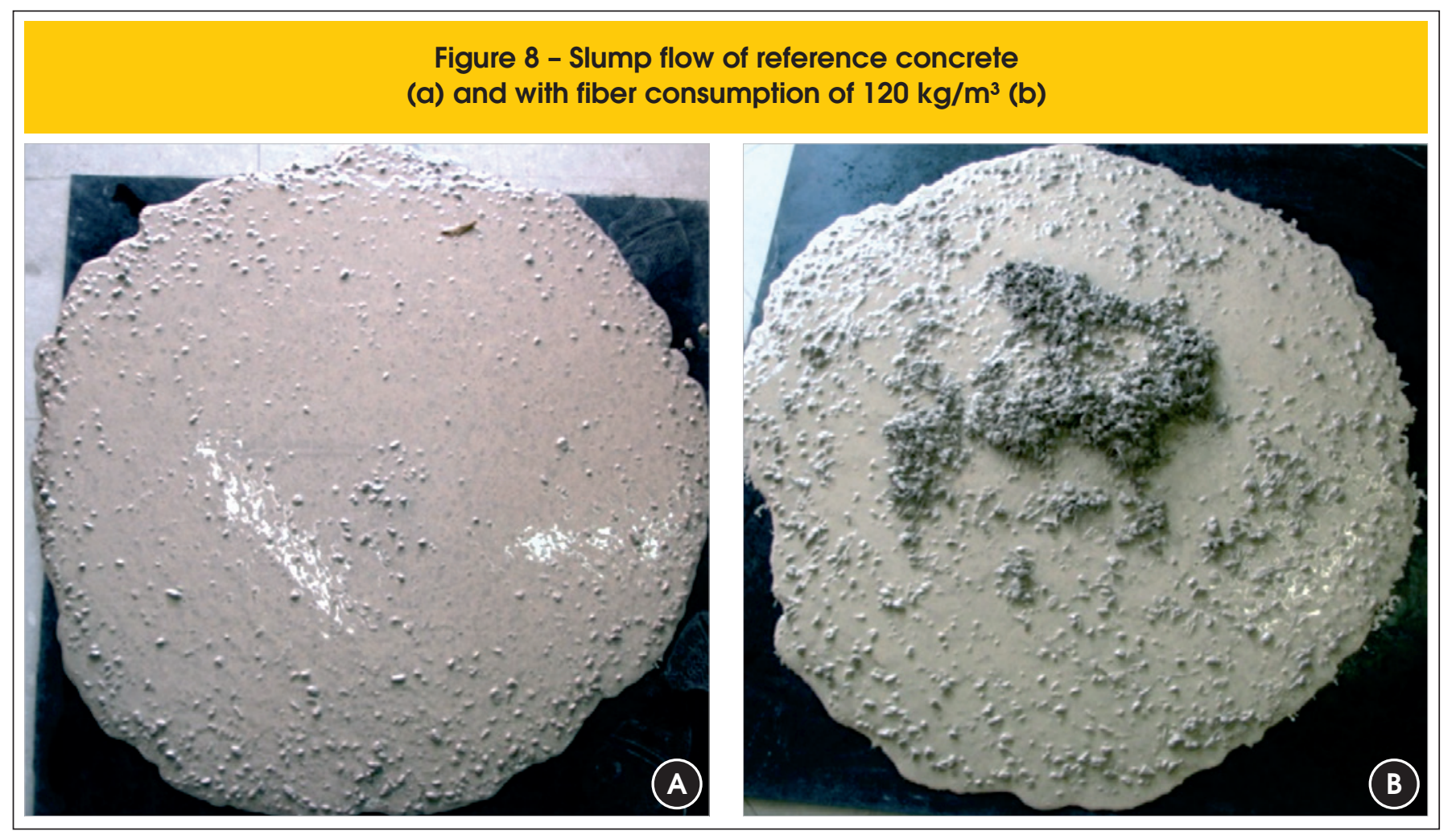

values were not significantly influenced by the fibers, showing that the test is unable to assess the effect of the fiber in the concrete mobility. Hence, the Slump Flow test is able to assess the potential risk of segregation of the material acting as a qualitative test method for the evaluation of FRSCC.

Regardless of the test used so far, the single point tests evaluate the concrete only in a single stress situation, in which the material only flows due to the gravity effect, reducing their results to numbers that must be within in a range of values. Although they are widely used, these kind of methods do not allow the analysis of variation in the behavior of the fresh concrete under different shear conditions.

In addition, the results of Slump Flow and L-Box tests can be influenced by factors such as the speed of execution [26]. This makes them highly dependent on the technical quality of the people involved, which does not happen with the rheometer test.

\subsection{Rheometry tests}

In rotational rheometry test it is possible to obtain more complete results than the obtained in previous tests. By applying different rotation speeds, it is possible to measure the material response at different in terms of shear torque as shown in Figure 9.

All concretes exhibit rheological behavior of pseudoplastic materials, and positive thixotropy profile (positive hysteresis area). The $20 \mathrm{~kg} / \mathrm{m}^{3}$ fiber consumption had no significant impact on the shear profile, but with volumes equal or higher than $80 \mathrm{~kg} / \mathrm{m}^{3}$, the influence of the fiber was very clear. The increment in shear torque was proportional to the increase in fiber content due to the rise in the contact frequency between the particles and changes of the flow lines.
A trend of growth of the plastic viscosity, directly proportional to the increased fiber content, was observed and the results are shown in Figure [10]. Note that the plastic viscosity presented is not according to the international system of units. Therefore, as a relationship between the shear torque and rotation is defined in this kind of test. Kuder et al. [14] claim that it is possible to prevail the effect of structural break of the solid material when lower addition of fiber. The mechanical interlocking effect is prevented when a critical amount is not reached. This information can be used to explain what happened during the Slump Flow test, where there was fiber

\section{Figure 9 - Shear profiles of the concrete mixtures related to rotation speed}

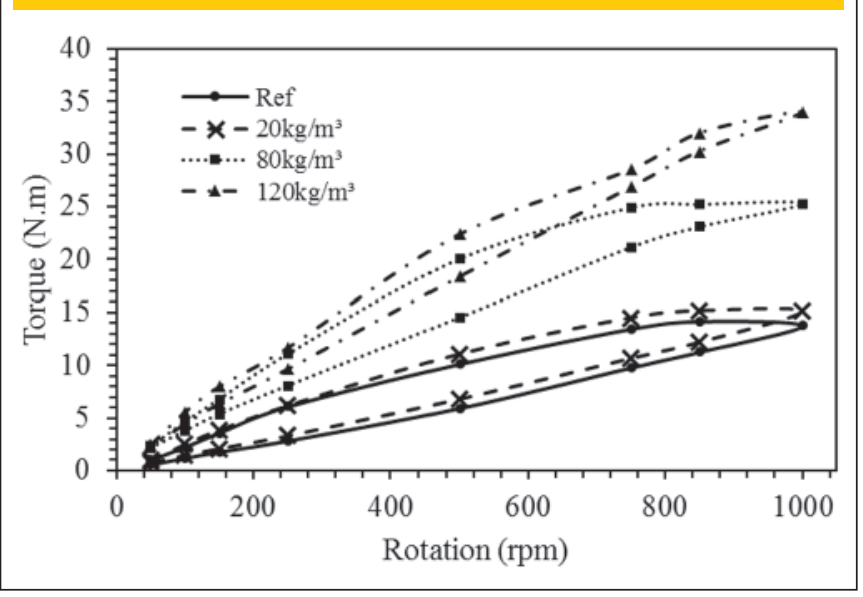




\section{Figure 10 - Plastic viscosity and yield toque related to fiber consumption}

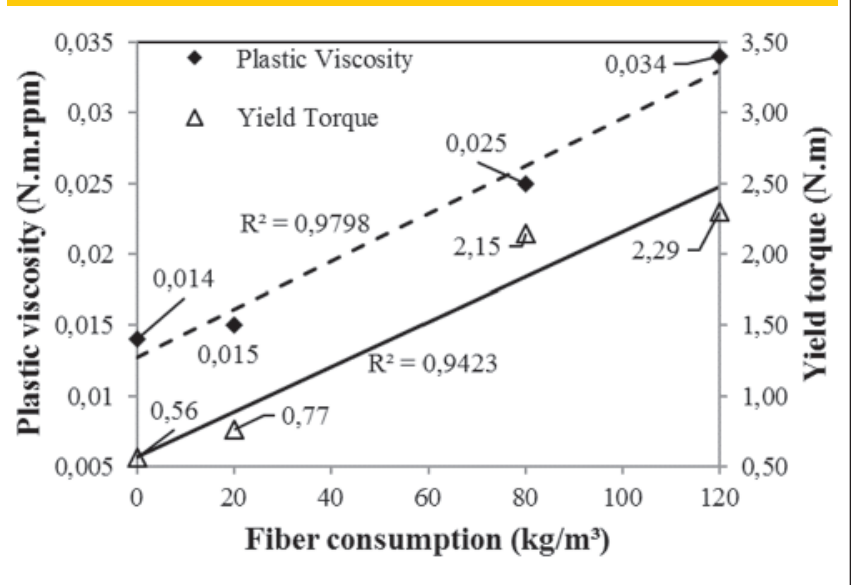

interlocking inside the suspension. However, according to this test assesments, all concrete mixtures were similar and in accordance with the technical standards. Therefore, the combination of test methods, as the Slump Flow, L-Box and rheometer, provide more complete analysis of the material in order to obtain a more coherent and correct development of the concrete mixture with adequate fresh state properties. This was especially clear in this experiment because the rheometer test was unable to point out the risk of segregation and problems with passing ability that other tests were able to demonstrate. Thus, there was no sign of segregation during the rheometer test because it acts like a mixer. Hence, for all the fiber contents used, the rheometer test was able to assess with precise measurements the effects of its addition. This shows the efficiency of the equipment used that assures the homogeneity of the fiber reinforced concrete throughout the whole test. On one hand, it is effective when considering the mixing conditions of the material. On the other hand, the passing ability and the risk of segregation are not directly controled in the rheometer test.

\subsection{Combined analysis of the results}

The information obtained from the Slump Flow and L-Box test methods are very limited and specific, measuring only one shear condition. Meanwhile, the rheometry data allows the clearly observation of the rheological profile, the change in plastic viscosity and yield torque of the concrete due to the increased amount of fibers. This does not mean that first tests cannot be used, but their results should be considered as a more qualitative and limited information to evaluate the concrete with fibers. Thus, the complementary use of different methodologies could provide a more comprehensive and efficient evaluation of the concrete behavior.

Correlations were made between the results from single point tests and from rotational rheometry test. It should be noted that the result from L-Box with maximum fiber content was removed from the analysis, since the configuration used in the test proved to be improper to the level of fibers content.

In Figure 11, the correlation between Slump Flow and passing ability with yield torque obtained from the rotational rheometry is shown. And Figure 12 shows the correlation of the same variables with plastic viscosity.

The slump flow had the lowest correlation coefficient when evaluated in function of the parameters measured by rotational rheometer. Meanwhile, the L-Box presented a more significant $R^{2}$ related to both the viscosity and the yield strength of the concrete mixtures. As previously studied by Damineli et al. [7] from analysis of the rheological profile measured in mixture from concrete plants, the Slump Flow of SCC has good correlation with yield stress and low with the plastic viscosity. In this study, the results were not similar to those obtained by the authors [7] because the fibers acted
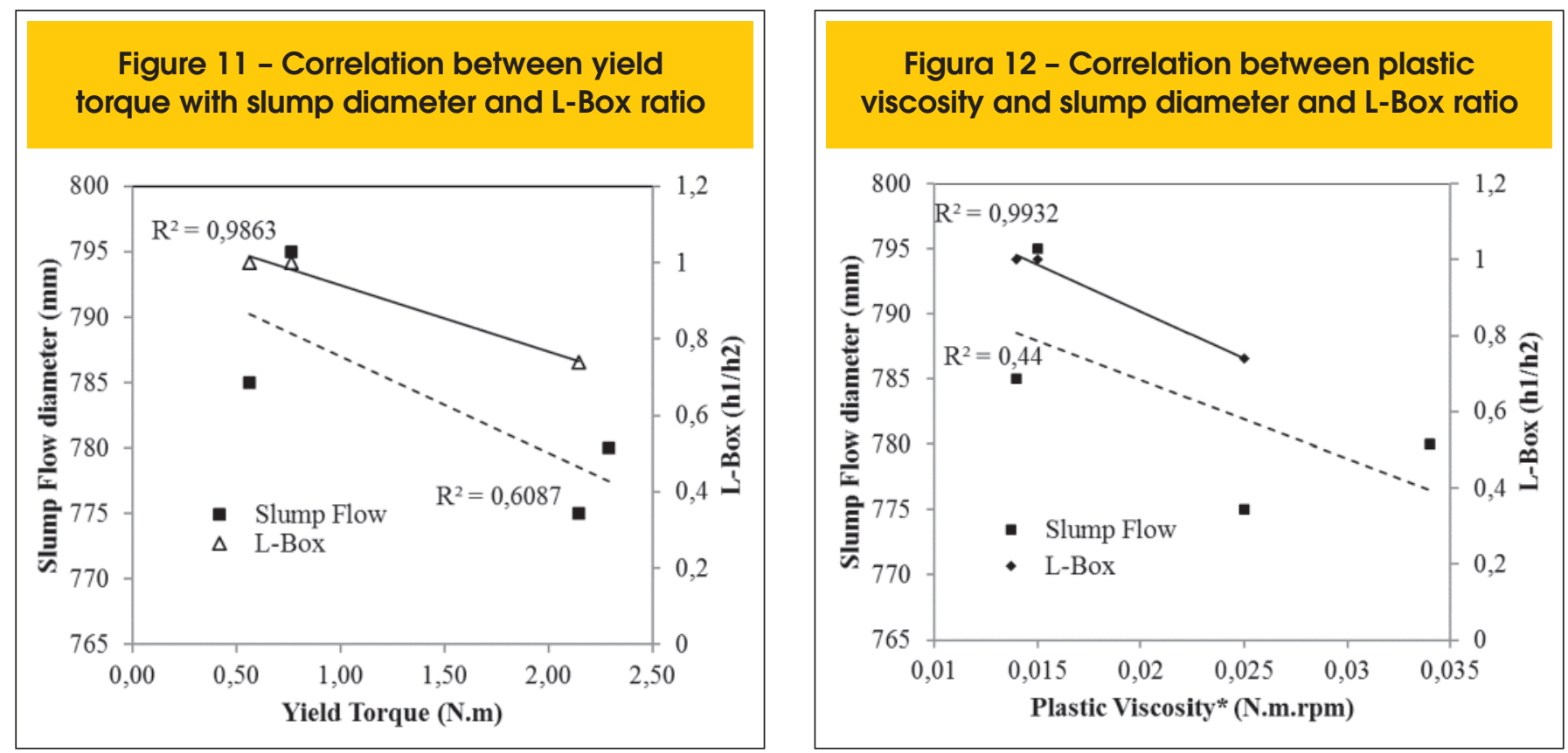
obstructing the free flow of the mixture, creating barriers for the relative movement of the materials.

This is due to the test setup, since the Slump Flow measures only the free flow of concrete, while the rheometer evaluates the material in confined situations, including interaction with the borders and with the shearing elements, which are characteristics closer to those observed in the L-Box test.

The loss of passing ability due to increasing fiber content, measured from the L-Box test, can be explained both by the increase in yield stress as the gain in the viscosity, assessed from rotational rheometry.

The rheometry, in turn, was more sensitive to short variations in the amount fibers, detecting changes even in the mixture with $20 \mathrm{~kg} /$ $\mathrm{m}^{3}$, and did not present limitation for measurements at the highest fiber amount $\left(120 \mathrm{~kg} / \mathrm{m}^{3}\right)$. On the contrary, the L-Box test is limited to a critical amount of fiber, as demonstrated in this study.

Parameters such as yield torque, hysteresis area and plastic viscosity could only be quantified through rheometry, and were accurate for all fibers values used, showing good applicability to the rheological tests in FRSCC. However, due the fact that the rheometer keeps the concrete constantly in motion, there was no possibility to evaluate the risk of segregation or the risk of blocking of the concrete by rebars.

\section{Conclusions}

The understanding of the influence of the presence of fibers in SCC is of great importance to improve the use of this technology. The commonly used single point tests may show limitations and low relation with physical parameters. The rotational rheometry comes as an additional resource for this kind of research. This kind of test could measure various stress levels and bring the possibility of correlating the results with those obtained in single point tests in order to better understand the prevailing rheological parameters acting in these methods.

The result of the Slump Flow showed little variation related to fiber content and classified all the mixtures as SCC according to the standard. Therefore, there was no good correlation with the yield stress, nor with the plastic viscosity. However, the visual analysis of the spread concrete allowed observation of the occurrence of segregation in free flow, which occurs in concrete with fiber contents of 80 and $120 \mathrm{~kg} / \mathrm{m}^{3}$.

Meanwhile, the L-Box test showed good correlation with rheological parameters and detected loss in passing ability of the concrete with increasing fiber content, which could be related to the increase in plastic viscosity and yield stress. Furthermore, it was able to clearly demonstrate the difficulties of passing ability when the fiber content was higher, which is not possible to assess through the use of rheometer. This clearly demonstrates that the combined use of the tests can provide a more comprehensive assessment of the suitability of the material. Furthermore, there is also the possibility of performing the L-Box test without the bars when there is no prediction of using hybrid reinforcement in the structures.

The result obtained through the rheometry allowed a more comprehensive interpretation of the characteristics of the concrete making it possible to evaluate the basic parameters variation according to the fiber content and the torque used. This enabled the concrete to be identified as a pseudoplastic material with positive thixotropy. The test also quantified the change in plastic viscosity and yield torque provoked by the variation of the fiber content. On the other hand, the rheometry could not give even a qualitative information about segregation and limitations of passing ability of FRSCC.

In conclusion, it is possible to affirm that, despite having limitations, the single point tests are able to provide additional information to assist the more precise analysis on the basic rheological properties of the concrete given by the rheometry tests. Further, as the rheological test allow a better reading of the rheological parameters regardless of fiber content used, its results are essential for the precise assessment of FRSCC.

\section{Acknowledgements}

The authors acknowledge CAPES and FAPESP for the financial support during the execution of this work.

\section{References}

[1] MEHTA, P. K.; MONTEIRO, P. J. M. Concrete: Microstructure, properties and materials., New York, 2006, McGrawHill, 3 ed. 2006

[2] AYDIN, A. C. Self compactability of high volume hybrid fiber reinforced concrete. Construction and Building Materials, v.21, n.6, 2007, p. 1149-1154.

[3] GRÜNEWALD, S. Performance-based design of self-compacting fibre reinforced concrete, 2004, 165p Tese (Doutorado) - Delft University of Technology, Netherlands.

[4] EL-DIEB, A. S.; REDA TAHA, M. M. Flow characteristics and acceptance criteria of fiber-reinforced self-compacted concrete (FR-SCC). Construction and Building Materials, v.27, n.1, 2012, p. 585-596.

[5] MARTINIE, L.; ROSSI, P.; ROUSSEL, N. Rheology of fiber reinforced cementitious materials: classification and prediction. Cement and Concrete Research, v.40, n.2, 2010, p. 226-234.

[6] FIGUEIREDO, A. D; CECCATO, M. R. Workability Analysis of Steel Fiber Reinforced Concrete Using Slump and Ve-Be Test. Materials Research, p. 1, 2015.

[7] DAMINELI, B. L. et al. Análise do perfil reológico de concretos dosados em central atraves de reometria aplicada em campo.IV Congreso Internacional de Tecnologia Del Hormigon. Mar del Plata. IV Congreso Internacional de Tecnologia Del Hormigon, 2010.

[8] ROUSSEL, N. Correlation between Yield Stress and Slump: Comparison between Numerical Simulations and Concrete Rheometers Results. Materials and Structures, 2007, p. 501-509.

[9] ABUKHASHABA, M. I.; MOSTAFA, M. A.; ADAM, I. A. Behavior of self-compacting fiber reinforced concrete containing cement kiln dust. Alexandria Engineering Journal, v.53, n.2, 2014, p. 341-354.

[10] MADANDOUST, R.; RANJBAR, M. M.; YASIN MOUSAVI, $S$. An investigation on the fresh properties of self-compacted lightweight concrete containing expanded polystyrene. Construction and Building Materials, v.25, n.9, 2011, p. 3721-3731.

[11] MEHDIPOUR, I. et al. Effect of workability characteristics on the hardened performance of FRSCCMs. Construction and Building Materials, v.40, 2013, p. 611-621. 
[12] NURUDDIN, M. F.; CHANG, K. Y.; MOHD AZMEE, N. Workability and compressive strength of ductile self-compacting concrete (DSCC) with various cement replacement materials. Construction and Building Materials, v.55, 2014, p. 153-157.

[13] SAHMARAN, M.; YURTSEVEN, A.; OZGUR YAMAN, I. Workability of hybrid fiber reinforced self-compacting concrete. Building and Environment, v.40, n.12, 2005, p. 1672-1677.

[14] KUDER, K. G. et al. Rheology of fiber-reinforced cementitious materials. Cement and Concrete Research, v.37, n.2, 2007, p. 191-199.

[15] FIGUEIREDO, A. D. Concreto com fibras. In: Concreto: Ciência e tecnologia. 2 ed. São Paulo, 2011, Instituto Brasileiro do Concreto (IBRACON). p. 1327-1365.

[16] FERRARA, L.; PRISCO, M.; LAMPERTI, M. G. L. Identification of the stress-crack opening behavior of HPFRCC : the role of flow-induced fiber orientation. 2010.

[17] EFNARC. The European Guidelines for Self-Compacting Concrete; specification, production and use. [s.I: s.n.]. Available in: www.efnarc.org/pdf/SCCGuidelinesMay2005.pdf.

[18] FIGUEIREDO, A. D. ; ESCARIZ, R. C. . Drainage concrete pipes with hybrid reinforcement. In: Second RILEM International Conference on Strain Hardening Cementitous Composites, 2011, Rio de Janeiro. Strain Hardening Cementitous Composites (SHCC2-Rio). Babneux: RILEM Publications S.A.R.L., 2011. p. 391-398.

[19] DE LA FUENTE, $A$. et al. Experiences in Barcelona with the use of fibres in segmental linings. Tunnelling and Underground Space Technology, v.27, n.1, 2012, p. 60-71.

[20] MAKITA, T.; BRÜHWILER, E. Tensile fatigue behaviour of Ultra-High Performance Fibre Reinforced Concrete combined with steel rebars (R-UHPFRC). International Journal of Fatigue, v.59, 2014, p. 145-152.

[21] MELO, K. A. Contribuição à dosagem de concreto auto-adensável com adição de fíler calcário. 2005, 183p Dissertação (Mestrado) - Universidade Federal de Santa Catarina, Florianópolis.

[22] FARES, G. Effect of slump cone orientation on the slump flow time (T50) and stability of sustainable self-compacting concrete containing limestone filler. Construction and Building Materials, v.77, 2015, p. 145-153.

[23] AKCAY, B.; TASDEMIR, M. A. Mechanical behaviour and fibre dispersion of hybrid steel fibre reinforced self-compacting concrete. Construction and Building Materials, v.28, n.1, 2012, p. 287-293.

[24] DHONDE, H.; MO, Y.; HSU, T. Passing Ability Tester for SelfConsolidating ConcreteJournal of ASTM International, 2006, p. 100330.

[25] GRÜNEWALD, S.; WALRAVEN, J. C. Parameter-study on the influence of steel fibers and coarse aggregate content on the fresh properties of self-compacting concrete. Cement and Concrete Research, v.31, 2001, p. 1793-1798.

[26] NGUYEN, T. L. H.; ROUSSEL, N.; COUSSOT, P. Correlation between L-box test and rheological parameters of a homogeneous yield stress fluid. Cement and Concrete Research, v.36, n.10, 2006, p. 1789-1796. 